\title{
Recognition of Political Education in Primary Schools
}

\author{
Yulia Ngatminiati \\ SD Negeri Beraja Asri \\ Way Jepara, Lampung Timur, Lampung, Indonesia \\ Yayuk Hidayah \\ Pendidikan Guru Sekolah Dasar, Universitas Ahmad Dahlan \\ Yogyakarta, Indonesia \\ Yayuk.hidayah@pgsd.uad.ac.id \\ Dianasari \\ Pendidikan Guru Sekolah Dasar, Universitas Muhammadiyah Cirebon \\ Cirebon, Indonesia \\ dianasari@umc.ac.id
}

Received: Dec 14, 2019

Revised: Feb 26, 2020

Accepted: April 6, 2020

\begin{abstract}
The purpose of this research was to know the efforts of political education in elementary schools. The research used descriptive qualitative research design involving the grade $V$ students of SD Negeri Beraja Asri, Way Jepara, East Lampung in Academic Year 2019/2020. Data collection techniques in this study using observation, interviews, and documentation. Data analysis using Miles and Huberman is data reduction, data presentation of conclusions. The results showed that political education in elementary schools could be done in various ways, namely through elementary school PPKn lessons, characterizations, and extracurricular activities. The study concluded that political education in SD Beraraja Asri Way Jepara is integrated into primary PPKn subjects and extracurricular activities.
\end{abstract}

Keywords: political education, elementary school

\begin{abstract}
Abstrak
Tujuan dari penelitian ini adalah untuk mengatahui usaha pendidikan politik di Sekolah Dasar. Metodologi penelitian menggunakan kualitaif deskriptif dengan objek penelitian adalah siswa-siswi kelas V SD Negeri Beraja Asri, Way Jepara, Lampung Timur Tahun Ajaran 2019/2020. Teknik Pengambilan data dalam penelitian ini menggunakan observasi, wawancara dan dokumentasi. Anaslisis data menggunakan Miles dan Huberman yaitu reduksi data, penyajian data penarikan kesimpulan. Hasil penelitian menunjukan bahwa pendidikan politik di Sekolah Dasar dapat di lakukan dengan berbagai cara yaitu melalui pelajaran PPKn Sekolah Dasar, penokohan, dan kegiatan luar kelas (ekstrakurikuler). Kesimpulan dalam penelitian ini adalah pendidikan politik di SD Negeri Beraraja Asri Way Jepara adalah terintegrasi dalam mata pelajaran PPKn SD dan kegiatan ekstrakurikuler.
\end{abstract}

Kata Kunci: pendidikan politik, sekolah dasar 


\section{Introduction}

Political education is axiom if it is associated with efforts to life educate of the nation, specifically in a democratic country, such as Indonesia. Democracy in Indonesia is showing its existence ${ }^{1}$, so it is not strange when confronting political education and democracy. Political education is beneficial for young people to be able for optimize efforts to advance nation. ${ }^{2}$ Systematic endeavors of political education in education need to be encouraged, because outputs of educational outcomes reflect quality of education. Quality of citizens cannot be separated from quality of education. ${ }^{3}$

Political education in elementary schools is an opportunity to provide a foundation of knowledge for students, considering that elementary school age is a good time to introduce concepts such as good and wrong. ${ }^{4}$ Political education is an effort to socialize politics, but packaging is adjusted conditions of each scope. Results of research in Turkey involving 75 social studies teachers, shows that teachers need to emphasize class politics. ${ }^{5}$ In a democratic country, political education is answer to realizing a healthy wheel of democracy. But in a country that faces political

1 E. Saepudin, K. Suryadi, and E. Malihah, "Deliberative Democracy in Digital Era," International Journal of Scientific E Engineering Research 9, no. 4 (2018), http://www.ijser.org.

2 A. Afriansyah, Pendidikan Politik Bagi Anak Bangsa (MediaIndonesia.Com, 2018).

${ }_{3}$ M. Amrullah and K. Hikmah, "Pendidikan Ramah Anak Dalam Standar Nasional Pendidikan Indonesia [Child Friendly Education in Indonesia's National Education Standards]," PEDAGOGIA: Jurnal Pendidikan 8, no. 1 (2019): 1-5, https://doi.org/10.21070/pedagogia. v8i1.1883.

4 Hidayah Y. et al., "Jurnal Iqra' : Kajian Ilmu Pendidikan," Jurnal Iqra' : Kajian Ilmu Pendidikan 3, no. 2 (2018): 329-344.

5 Z. KUŞ and Ö TARHAN, "POLITICAL EDUCATION IN SOCIAL STUDIES CLASSROOMS: A PERSPECTIVE FROM TURKEY," Eğitimde Kuram ve Uygulama Journal of Theory and Practice in Education 12, no. 3 (2017b): 464-483. instability, political education is an urgent need in building a democratic mindset. ${ }^{6}$

There are many researches that examine political education. Research in America investigating effects of political socialization in schools, results show curriculum in schools is effective in eliciting political knowledge, but not in realm of attitude. Attributes that influence political attitudes are class climate, participation in school activities, and school organization. ${ }^{7}$ Furthermore, investigating main functions of social primary education schools relating to political participation for 25 years provides an understanding that children's ways of thinking in political aspects are related to their lives, for example justice, authority and partiality. ${ }^{8}$ Meanwhile focuses research on function of schools in political education results in schools being an important instrument in political education. Political learning in schools can be learned through extracurricular activities and other outside class activities. ${ }^{9}$

Study about aspects of political education shows that political education consists of three aspects, firstly cognitive relating to development of knowledge, secondly affective aspects of character building, and thirdly psychomotor aspects related to skills. ${ }^{10}$ Results of study illustrate that there are various needs that are due to the urgency of political education. In addition, there is no research that

${ }^{6}$ U. Quraishi and F. Rahman, "Political Education for Democracy in Schools," Gomal University Journal of Research 25, no. 1 (2009): 25-36.

7 L. H. Ehman, "The American School in the Political Socialization Process," Review of Educational Research 50, no. 1 (1980): 99-119., https://doi. org/10.3102/00346543050001099.

8 S. B. Palonsky, "Political Socialization in Elementary Schools," The Elementary School Journal 87, no. 5 (1987): 493-505, https://doi.org/10.1086/461512.

9 W. N. Fajar, “PELAKSANAAN PENDIDIKAN POLITIK DI SEKOLAH DALAM MENINGKATKAN KESADARAN POLITIK SISWA," Khazanah Pendidikan Jurnalnasional.Ump.Ac.Id., 2014, ump.ac.id.

${ }_{10}$ Halking, "Aspek-Aspek Pendidikan Politik Dalam Kehidupan Demokrasi Untuk Mewujudkan Kecakapan Warga Negara Yang Smart and Good Citizenship," Https://Journal.Unnes.Ac.Id/Sju/Index.Php/Snh 4, no. 3 (2018): 1205-1228. 
investigates political education in elementary schools, so this research is expected to be able to provide answers to research problems that have not been an issue in previous studies.

Focus of this research is implementation of political education in elementary schools. Formulation problem is "How to implementation political education in Elementary School Beraraja Asri, Way Jepara, East Lampung?". Benefit of this research is practically able to contribute thought of political education efforts in elementary schools. While theoretical benefit is being able to become a theoretical basis for further researchers with the same research interest, namely politics in elementary schools.

\section{Method}

This type of research was descriptive qualitative. Qualitative research is based on philosophy of postpositivism that used to examine under old conditions. ${ }^{11}$ Descriptive research is used to describe natural phenomena that occur. ${ }^{12}$ Author used a descriptive qualitative approach in this study with aim to more flexible and comprehensive in capturing phenomenon of political education in elementary schools. Qualitative descriptive is used to describe natural phenomena by emphasizing characteristics and linkages. ${ }^{13}$

Location of research was Beraja Asri's elementary school, Way Jepara, East Lampung, Academic Year 2019/2020. Objects are fifth grade teachers and fifth grade students. Technique of collecting data uses observations conducted inside and outside classroom, structured interviews with fifth grade teachers of Beraja Asri's elementary school, Way Jepara and fifth grade students who are considered to provide appropriate information research theme. Documentation

11 Sugiyono, Metode Penelitian Kuantitatif Kualitatif Dan RED (Bandung: Alfabeta, 2012).

12 L. J. Moleong, Metodologi Penelitian Kualitatif (Bandung: PT Remaja Rosdakarya, 2002).

13 N. S. Sukmadinata, Metode Penelitian Pendidikan (Bandung: PT Remaja Rosdakarya, 2011). collection form of class diaries, books, journals, magazines that can provide information for researchers. Documentation study is collection of documents in accordance with the problem then conducted an intensive study. ${ }^{14}$

Analysis data that researchers use is Miles and Huberman model of data reduction, data presentation and drawing conclusions. ${ }^{15}$ Data analysis is process of compiling results of interviews, observations and documentation into categories so that others can understand. ${ }^{16}$

\section{Result and Discussion}

In results and discussion section, researcher attempts to present an analysis of research questions.

\section{Political Education in Elementary School}

How is implementation of political education in Elementary School Beraraja Asri at Way Jepara, East Lampung? Results of research found that implementation of political education in Elementary School Beraraja Asri at Way Jepara, East Lampung, there were several means of political education through elementary school civics, through extracurricular activities and through characterizations. Furthermore, the research findings will be discussed by researchers in following units.

\section{Political Education Through Elementary School Civics}

In Indonesia subject of Civic Education is a subject taught from Elementary School to Higher Education, according to the rules in Article 37 paragraph (1) and (2) of Law number 20 of 2003 about National Education System. In various countries, application of Civic Education is different in form. In Singapore,

14 A. Komariah and D. Sator, Metode Penelitian Kualitatif (Bandung: Alfabeta, 2011).

15 M. B. Miles and A. M. Huberman, Analisis Data Kualitatif (Jakarta: UI-Press., 2009).

16 Sugiyono, Metode Penelitian Kuantitatif, Kualitatif Dan RED (Bandung: Alfabeta, 2009). 
Civic Education has been in compulsory social studies subjects in secondary schools since $2001 .^{17}$ In Malaysia, Civic Education is conceptualized by developing good citizens with patriotic personalities. ${ }^{18}$ In American schools, Civic Education is designed to encourage students to be active in their communities. ${ }^{19}$

Implementation of political in civic subject of Elementary School, is something that can be done considering the new mission in civic paradigm is to develop the characteristics of citizens. The mission of Civics with their new paradigm is to develop psychopedagogical and socio-andragogical aims to develop three characteristics, namely civic intelligence, civic responsibility and civic participation. ${ }^{20}$ Based on interviews with grade $\mathrm{V}$ teachers of Beraja Asri's elementary school at Way Jepara, East Lampung, civic subjects through civic subject of Elementary School, teachers can provide political education to students. "...civic subject in elementary school is one of the means in learning political education. Even though uses elementary way to lead students in political education..." (YES, 2019).

Based on the results of the interview stated that civic subject in elementary school became a means of conducting political education. Political education through civic subject in elementary school is an effort of political education on cognitive aspects. Cognitive aspects of political education are aspects that emphasize development

17 J. B.-Y. SIM, "Citizenship Education and Social Studies," International Journal of Citizenship and Teacher Education 1, no. 1 (2005).

18 H. Mahmood, "Thesis Doctor of Philosophy: Civics and Citizenship Education in Malaysia : The Voice of Micro Policy Enactors" (Cardiff University., 2014).

19 A. R. Lin, "Citizenship Education in American Schools and Its Role in Developing Civic Engagement: A Review of The Research," Educational Review, February 2015, https://doi.org/10.1080/00131911.2013.813440.

${ }_{20}$ U. S. Winataputra and Sapriya, "Paradigma Baru PKn Di SD/MI," Modul 1 Paradigma Baru PKn Di SD/MI, 2014, 1-46. of citizens' political knowledge. ${ }^{21}$ As a comparison with the findings of previous research on political education in elementary schools. Research in Turkey involving 75 social studies teachers for political subjects education and observing the intraclass application of 12 social studies teachers for 10 weeks. Resulting in no difference between student views and intraclass applications. Meanwhile the teacher emphasized need to teach political subjects in social studies classes and provide information about the political process. ${ }^{22}$ Other findings, an analysis of elementary school textbooks in China and Taiwan found that in analysis of two sets of textbook 1 there were following topics: "basic virtues" of personal and attributes; social relations that presented in form of social units and personal interaction patterns with emphasis on manual labor, agriculture, nature and education. ${ }^{23}$

In implementation of political education of civic subject in Elementary Schools is an effort to care for the progress of the Indonesian people. Moreover, in global era, learning is about how children learn to find themselves in the world. ${ }^{24}$ Globalization is now widely understood as a worldwide process, and has resulted in various aspects of human life undergoing change. In the field of education, learning is required to put more emphasis on skills needed in the global era. But on other hand, "constructivism in practice" is a concept of ambiguity that arises among stakeholders in

${ }^{21}$ Halking, "Aspek-Aspek Pendidikan Politik Dalam Kehidupan Demokrasi Untuk Mewujudkan Kecakapan Warga Negara Yang Smart and Good Citizenship,."

${ }^{22}$ KUŞ and TARHAN, "POLITICAL EDUCATION IN SOCIAL STUDIES CLASSROOMS: A PERSPECTIVE FROM TURKEY."

${ }^{23}$ R. Martin, "The Socialization of Children in China and on Taiwan: An Analysis of Elementary School Textbooks," The China Quarterly, no. 62 (1975): 242, https://doi.org/10.1017/s0305741000007013.

${ }^{24}$ L. Parmenter et al., "Locating Self in the World: Elementary School Children in Japan, Macau and Hong Kong," Compare: A Journal of Comparative and International Education 30, no. 2 (2000): 133-144., https:// doi.org/10.1080/03057920050034084. 
educational companies because constructivism is used as a basis for teaching. ${ }^{25}$

Efforts to implement political education in primary schools are part of efforts to care of democracy in Indonesia for the future. In a democratic society, concern for condition of state is a must, and can begin in childhood. At this stage, schools play a very important role. ${ }^{26}$ Results of a study of Role of Family and Role of Schools on formation of political orientation of high school students in Sleman district at 2015 produced, role of family in forming political orientation of high school students has a significant influence. Role of schools in forming political orientation of high school students has a significant influence on the value of arithmetic $(4,821)$. This means that role of family and school, together can have a positive and significant influence on formation of political orientation of state high school students. ${ }^{27}$ Meanwhile, Civic Education Longitudinal Research shows that Citizenship Education activities in schools can indeed have an effect, not only in short term (as shown by previous research in UK), but also in medium term (by encouraging political involvement once students leave school boundaries ). ${ }^{28}$

Implementation of political education in civil subject of Elementary Schools through thematic is in line with concept of curriculum

25 M. Windschitl, "Framing Constructivism in Practice as the Negotiation of Dilemmas: An Analysis of the Conceptual, Pedagogical, Cultural, and Political Challenges Facing Teachers," Review of Educational Research 72, no. 2 (2002): 131-175, https://doi. org/10.3102/00346543072002131.

${ }^{26}$ W. Althof and M. W. Berkowitz, "Moral Education and Character Education: Their Relationship and Roles in Citizenship Education," Journal of Moral Education 35, no. 4 (2006): 495-518, https://doi. org/10.1080/03057240601012204.

${ }_{27}$ M. Hardian, "Pengaruh Peran Keluarga Dan Peran Sekolah Terhadap Pembentukan Orientasi Politik Siswa SMA Negeri Se Kabupaten Sleman Pada Pemilihan Umum Kepala Daerah Kabupaten Sleman Tahun 2015" (Universitas Negeri Yogyakarta, 2016).

${ }^{28}$ A. Keating and J. G. Janmaat, “Education Through Citizenship at School: Do School Activities Have a Lasting Impact on Youth Political Engagement?," Parliamentary Affairs 69, no. 2 (2015): 409-429, https://doi. org/10.1093/pa/gsv017. development in 2013. That is through thematic learning, students will understand concepts that are accepted in a whole and realistic way. ${ }^{29}$ Following table 1 changes patterns in the 2013 curriculum.

Table 1. Changes patterns in the last curriculum and curriculum of 2013

\begin{tabular}{|c|c|c|}
\hline $\begin{array}{l}\text { Competency Based } \\
\text { Curriculum (2004) }\end{array}$ & $\begin{array}{l}\text { Education Unit } \\
\text { Level Crriculum } \\
(2006)\end{array}$ & Curriculum of 2013 \\
\hline \multicolumn{2}{|c|}{$\begin{array}{l}\text { Graduate competency standards are derived } \\
\text { from content standards }\end{array}$} & $\begin{array}{l}\text { Graduate competency standards derived } \\
\text { from real needs }\end{array}$ \\
\hline \multicolumn{2}{|c|}{$\begin{array}{c}\text { Content standards are formulated based on } \\
\text { objectives of subject (competency standards of } \\
\text { graduate subjects) broken down into standard } \\
\text { competencies and basic competencies of } \\
\text { subjects. }\end{array}$} & $\begin{array}{l}\text { Content standards are derived from } \\
\text { graduate competency standards through } \\
\text { core subjects that are free of subjects }\end{array}$ \\
\hline \multicolumn{2}{|c|}{$\begin{array}{l}\text { Separation between the subjects forming } \\
\text { attitude, forming skills, and forming } \\
\text { knowledge. }\end{array}$} & $\begin{array}{l}\text { All subjects must contribute to the } \\
\text { formation of attitudes, skills, and } \\
\text { knowledge. }\end{array}$ \\
\hline \multicolumn{2}{|c|}{ Competence is derived from subjects } & $\begin{array}{l}\text { Subjects are derived from the competencies } \\
\text { to be achieved. }\end{array}$ \\
\hline \multicolumn{2}{|c|}{$\begin{array}{l}\text { Subjects are separated from each other, like a } \\
\text { separate set of subjects }\end{array}$} & $\begin{array}{l}\text { All subjects are bound by core } \\
\text { competencies (each class). }\end{array}$ \\
\hline
\end{tabular}

Source: Curriculum Center (2014)

Political education at elementary school level relies on ability of teachers to collaborate learning and methods. Learning in children needs to prioritize teaching skills. ${ }^{30}$ While learning in elementary schools is planned learning, assessed and evaluated. According to Minister of National Education Regulation No. 41/2007 concerning Process Standards for Primary and Secondary Education Units, it is explained that: "learning is process of interaction of students with teachers and learning resources in an environment study. Learning process needs to be planned, implemented, assessed and monitored. Implementation of learning is implementation of the Learning Implementation Plan. Learning activities include preliminary activities, core activities and closing activities."

Political education through elementary civic subject puts forward real values for students, such as the value of honesty, respect, opinion, and responsibility. This is intended so that students do not feel forced into

29 L. I. Purwati and S. Amri, Panduan Memahami Kurikulum 2013 (Jakarta: Prestasi Pustaka, 2013).

30 A. Asy'ari and R. Abidin, "Gardening Sebagai Media Edukasi Untuk Meningkatkan Kemampuan Motorik Anak [ Gardening as an Educational Media to Improve Children ' s Motor Ability ]," PEDAGOGIA: Jurnal Pendidikan 8, no. 1 (2019): 35-43, https://doi. org/,https://doi.org/10.21070/pedagogia.v7i2.1715. 
learning. Integrated learning in SD / MI can be simply applied by combining material and approaches to form a theme as a reference. ${ }^{31}$ In elementary civic subject subjects, students in grade V of Beraraja Asri's Elementary School at Way Jepara, East Lampung are invited to politics study by paying attention to principle of problem solving, according to students' thinking processes, namely cohesiveness and individual differences. Student's thought process is student's ability to solve problems. ${ }^{32}$

\section{Political Education Through Extracurricular Activities}

As a formal educational institution, Beraraja Asri's Elementary School at Way Jepara, East Lampung has extracurricular activities such as scouts and traditional dance. Extracurricular activities function to deliver students to develop according to their needs. ${ }^{33}$ In accordance with results of an interview with scoutmaster of SD Negeri Beraja Asri, Way Jepara, East Lampung, it was found that in scouting activities students were directed to be able to work together, respect and put forward deliberations as in the following interview passages, " ... in scouting students are invited cooperate in teams and deliberate in overcoming problems ... "(YN, 2019).

Through extracurricular activities, political education is manifested in activities that encourage students to prioritize democratic values based on Pancasila, with one of aims to teach deliberation in problem solving. Political

31 U. Murfiah, "MODEL PEMBELAJARAN TERPADU DI SEKOLAH DASAR Uum Murfiah (Dosen Prodi PGSD FKIP Universitas Pasundan Bandung)," JURNAL PESONA DASAR 1, no. 5 (2017): 57-69.

32 G. S. Sidik and F. Nugraha, "Proses Berpikir Pada Pemahaman Perkalian Dan Pembagian Pecahan [ The Process of Thinking in Mathematical Understanding of Primary School Students Regarding Counting Operation Materials Multiplication and Division of Fractions ]," PEDAGOGIA: Jurnal Pendidikan 8, no. 1 (2019): 45-52, https://doi.org/10.21070/pedagogia.v8i1.1953.

${ }_{33}$ P. Lestari Sukanti, "Membangun Karakter Siswa Melalui Kegiatan Intrakurikuler Ekstrakurikuler, Dan Hidden Curriculum (Di SD Budi Mulia Dua Pandeansari Yogyakarta)," Jurnal Penelitian 10, no. 1 (2016): 71-96. education as an effort to instill national politics based on Pancasila values. ${ }^{34}$ In a large Indonesian dictionary, deliberation is interpreted as a joint discussion with intention of reaching a decision and settlement, in addition it is used as a means of negotiation or consultation. ${ }^{35}$

As a comparison, political education through extracurricular activities promotes democratic values. Results of some research at American high schools produce that secondary school extracurricular activities are part of informal learning resources. Extracurricular activities are also intended to teach the attributes of citizenship. Although in this study did not find a direct relationship between participation in school extracurricular activities and attitudes towards politics, students felt integrated into the system, this feeling of integration was related to social trust. Students who have social confidence have a more positive attitude towards politics. ${ }^{36}$

Other research results on role of extracurricular activities in predicting adult political behavior, show that instrumental extracurricular activities such as student governance, positively predict political engagement in early adulthood, socialization, political interests, political awareness, and community leadership attitudes. Results of research concluded that extracurricular participation did play a role in developing political involvement. ${ }^{37}$

Extracurricular activities in School have a mission in developing students' abilities both cognitive, affective and psychomotor.

34 J. W. Batawi, “Tingkat Kesadaran Politik Pemilih Pemula Dalam Pilkada," Jurnal UNIERA 2, no. 2 (2013).

35 “Departemen Pendidikan Dan Kebudayaan," in Kamus Besar Bahasa Indonesia (Jakarta: Balai Pustaka, 1989).

${ }^{36}$ D. Ziblatt, "High School Extracurricular Activities and Political Socialization," The ANNALS of the American Academy of Political and Social Science 361, no. 1 (1965): 20-31, https://doi.org/10.1177/000271626536100103.

37 J. L. Glanville, “Political Socialization or Selection? Adolescent Extracurricular Participation and Political Activity in Early Adulthood," Social Science Quarterly 80, no. 2 (1999): 279. 
Extracurricular activities are part of meeting needs of students. Extracurricular activities are a complement to intracuricular learning activities. ${ }^{38}$ There are several characters that can be developed in extracurricular activities. Results of research on extracurricular activities in developing character values of students to become good citizens at KORPRI Banjarmasin High School resulted in character values developed in extracurricular activities being hard work, discipline, responsibility, religious, democratic, curiosity, friends or communicative, patriotism, honesty, tolerance, spirit of nationalism, love of peace, creative, care for environment, care for social, appreciate achievement, like to read and be independent. ${ }^{39}$ Future studies of qualitative case studies in private primary schools in Turkey explain role of extra-curricular school-based activities as contemporary trends in building values of active citizenship and competence in students. ${ }^{40}$

Political education through extracurricular activities is part of realizing good citizenship in democracy. Although this research is limited to elementary school level, but based on the findings during study, a red thread is seen that political education through extracurricular activities at any school level has a role in developing student character. Based on observations made by researchers at Beraja Asri's elementary school, it is known that students who take extracurricular activities carry out activities in extracurricular enthusiastically coupled with playing and supervising from supervisor teacher. Research

38 R. Lutan, Pengelolaan Interaksi Belajar Mengajar Intrakurikuler, Kourikuler Dan Ekstrakurikuler (Jakarta: Departemen Pendidikan dan Kebudayaan Universitas Terbuka, 1986).

39 N. Yanti, R. Adawiah, and H. Matnuh, "PELAKSANAAN KEGIATAN EKSTRAKURIKULER DALAM RANGKA PENGEMBANGAN NILAI-NILAI KARAKTER SISWA UNTUK MENJADI WARGA," Jurnal Pendidikan Kewarganegaraan, no. 6 (2016): 963-970.

40 F. Keser, A. Yildirim, and H. Akar, "The Role of Extracurricular Activities in Active Citizenship Education," Journal of Curriculum Studies 43, no. 6 (2011): 809-837, https://doi.org/10.1080/00220272.2011.591433. findings are supported by previous research conducted by Fajar ${ }^{41}$, showing that schools are an important component in political education and one of efforts to instill political awareness is through student council and extracurricular activities. Political education through extracurricular activities at Beraja Asri's Elementary School, Way Jepara, East Lampung is an effort to provide political awareness for students. Political awareness efforts are important considering that this era of students is very close to digital life. Problems arise with digital literacy and psychological development of children and adolescents ${ }^{42}$, so that with presence of extracurricular activities that tuck political education can be a meaningful experience for students so as to build their basic knowledge.

Political education through extracurricular activities at Beraja Asri's Elementary School, Way Jepara, East Lampung has become a vehicle for growing political maturity of students. Through interaction, different views, students will learn massively about overcoming problems and mapping problems. Besides political education through extracurricular activities can also help teachers in providing political education for students. Difficulty of Indonesian teachers in trying to implement learning according to times is a demand in providing solutions in developing learning in accordance with Indonesian context. ${ }^{43}$

41 Fajar, “PELAKSANAAN PENDIDIKAN POLITIK DI SEKOLAH DALAM MENINGKATKAN KESADARAN POLITIK SISWA."

42 N. Pratiwi, N. Pritanova, and Prodi, "Pengaruh Literasi Digital Terhadap Psikologis Anak Dan Remaja," Jurnal Ilmiah Program Studi Pendidikan Bahasa Dan Sastra Indonesia 6, no. 1 (2017): 11-24, https://doi.org/10.22460/ semantik.v6i1.p11-24.

43 W. Sopandi, Y. A. Pratama, and H. Handayani, "Sosialisasi Dan Workshop Implementasi Model Pembelajaran Dasar Dan Menengah [ Dissemination and Implementation Workshop of RADEC Learning Models for Primary and Secondary Education Teachers ]," PEDAGOGIA: Jurnal Pendidikan 8, no. 1 (2019): 19-34, https://doi.org/10.21070/pedagogia.v8i1.1853. 
Education is a conscious effort with the aim of developing potential of students. ${ }^{51}$ In detail, implementation of political education in Beraja Asri's elementary school, Way Jepara, East Lampung is in following table 2.

Tabel 2. Implementation of political education in Beraja Asri's elementary school in Way Jepara, East Lampung

\begin{tabular}{|l|l|}
\hline $\begin{array}{l}\text { Implementation of political education } \\
\text { in Beraja Asri'selementary school, } \\
\text { Way Jepara, East Lampung }\end{array}$ & Political education aspects \\
\hline $\begin{array}{l}\text { Political Education Through zcivic } \\
\text { subject Elementary School }\end{array}$ & Cognitive aspects \\
\hline $\begin{array}{l}\text { Political Education Through } \\
\text { Extracurricular Activities }\end{array}$ & Psychomotor aspects \\
\hline $\begin{array}{l}\text { Political Education through } \\
\text { Characterization }\end{array}$ & Affective Aspects \\
\hline
\end{tabular}

\section{Acknowledge}

Researcher is glad thank full to Elementary School Beraja Asri, Way Jepara, East Lampung for being given opportunity for researchers to complete this research. Thank you for all teachers who accepted for interview and thanks for reviewer for his response to this article.

\section{References}

Afandi, R. "Integrasi Pendidikan Karakter Dalam Pembelajaran IPS Di Sekolah Dasar." PEDAGOGIA 1, no. 1 (2011)

Afriansyah, A. Pendidikan Politik Bagi Anak Bangsa. MediaIndonesia.Com, 2018.

Althof, W., and M. W. Berkowitz. "Moral Education and Character Education: Their Relationship and Roles in Citizenship Education." Journal of Moral Education35,no.4(2006):495-518.https:// doi.org/10.1080/03057240601012204.

Amrullah, M., and K. Hikmah. "Pendidikan Ramah Anak Dalam Standar Nasional Pendidikan Indonesia [Child Friendly Education in Indonesia's National Education Standards]." PEDAGOGIA: Jurnal Pendidikan 8, no. 1 (2019) https://

$\overline{\mathrm{rg} / 10.1080 / 00933104.2000 .10505911 .}$

${ }^{51}$ R. Afandi, “Integrasi Pendidikan Karakter Dalam Pembelajaran IPS Di Sekolah Dasar," PEDAGOGIA 1, no. 1 (2011): 85-98. doi.org/10.21070/pedagogia.v8i1.1883.

Asy'ari, A., and R. Abidin. “Gardening Sebagai Media Edukasi Untuk Meningkatkan Kemampuan Motorik Anak [ Gardening as an Educational Media to Improve Children ' s Motor Ability ]." PEDAGOGIA: Jurnal Pendidikan 8, no. 1 (2019) https://doi.org/,https://doi. org/10.21070/pedagogia.v7i2.1715.

Batawi, J. W. "Tingkat Kesadaran Politik Pemilih Pemula Dalam Pilkada." Jurnal UNIERA 2, no. 2 (2013).

“Departemen Pendidikan Dan Kebudayaan." In Kamus Besar Bahasa Indonesia. Jakarta: Balai Pustaka, 1989.

Ehman, L. H. "The American School in the Political Socialization Process." Review of EducationalResearch50,no.1(1980)https:// doi.org/10.3102/00346543050001099.

Fajar, W. N. “PELAKSANAAN PENDIDIKAN POLITIK DI SEKOLAH DALAM MENINGKATKAN KESADARAN POLITIK SISWA." Khazanah Pendidikan Jurnalnasional.Ump.Ac.Id., 2014. ump. ac.id.

Glanville, J. L. "Political Socialization or Selection? Adolescent Extracurricular Participation and Political Activity in Early Adulthood." Social Science Quarterly 80, no. 2 (1999)

Halking. “Aspek-Aspek Pendidikan Politik Dalam Kehidupan Demokrasi Untuk Mewujudkan Kecakapan Warga Negara Yang Smart and Good Citizenship,." Https://Journal.Unnes.Ac.Id/Sju/Index. Php/Snh 4, no. 3 (2018)

Hardian, M. “Pengaruh Peran Keluarga Dan Peran Sekolah Terhadap Pembentukan Orientasi Politik Siswa SMA Negeri Se Kabupaten Sleman Pada Pemilihan Umum Kepala Daerah Kabupaten Sleman Tahun 2015." Universitas Negeri Yogyakarta, 2016.

Hidayah, Y., L. Retansari, N. Ulfah, and Suyitno. "Jurnal Iqra' : Kajian Ilmu Pendidikan." 
Jurnal Iqra' : Kajian Ilmu Pendidikan 3, no. 2 (2018)

Kahne, J., M. Rodriguez, K. Thiede, and B. Smith. "Developing Citizens for Democracy? Assessing Opportunities to Learn in Chicago's Social Studies Classrooms." Theory \& Research in Social Education 28, no. 3 (2000) https://doi.org /10.1080/00933104.2000.10505911.

Karim, A. "PENERAPAN METODE PENEMUAN TERBIMBING DALAM PEMBELAJARAN MATEMATIKA UNTUK MENINGKATKAN PEMAHAMAN KONSEP DAN KEMAMPUAN BERPIKIR KRITIS SISWA SEKOLAH DASAR." Edisi Khusus No. 1, no. 1 (Agustus 2011)

Keating, A., and J. G. Janmaat. "Education Through Citizenship at School: Do School Activities Have a Lasting Impact on Youth Political Engagement?" Parliamentary Affairs 69, no. 2 (2015) https://doi.org/10.1093/pa/gsv017.

Keser, F., A. Yildirim, and H. Akar. “The Role of Extracurricular Activities in Active Citizenship Education." Journal of Curriculum Studies 43, no. 6 (2011). https://doi.org/10.1080/00220272.2011.5 91433.

Komariah, A., and D. Sator. Metode Penelitian Kualitatif. Bandung: Alfabeta, 2011.

KUŞ, Z., and Ö TARHAN. "POLITICAL EDUCATION IN SOCIAL STUDIES CLASSROOMS: A PERSPECTIVE FROM TURKEY." Eğitimde Kuram ve Uygulama Journal of Theory and Practice in Education 12, no. 3 (2017b)

Lin, A. R. "Citizenship Education in American Schools and Its Role in Developing Civic Engagement: A Review of The Research." Educational Review, February 2015. https://doi.org/10.1080/00131911.2 013.813440.

Lutan, R. Pengelolaan Interaksi Belajar
Mengajar Intrakurikuler, Kourikuler Dan Ekstrakurikuler. Jakarta: Departemen Pendidikan dan Kebudayaan Universitas Terbuka, 1986.

Mahmood, H. "Thesis Doctor of Philosophy: Civics and Citizenship Education in Malaysia: The Voice of Micro Policy Enactors." Cardiff University., 2014.

Martin, R. "The Socialization of Children in China and on Taiwan: An Analysis of Elementary School Textbooks." The China Quarterly, no. 62 (1975). https:// doi.org/10.1017/s0305741000007013.

Miles, M. B., and A. M. Huberman. Analisis Data Kualitatif. Jakarta: UI-Press., 2009.

Minderop, A. Metode Karakterisasi Telaah Fiksi. Jakarta: Yayasan Pustaka Obor Indonesia, 2011.

Moleong, L. J. Metodologi Penelitian Kualitatif. Bandung: PT Remaja Rosdakarya, 2002.

Murfiah, U. "MODEL PEMBELAJARAN TERPADU DI SEKOLAH DASAR Uum Murfiah (Dosen Prodi PGSD FKIP Universitas Pasundan Bandung)." JURNAL PESONA DASAR 1, no. 5 (2017):

Palonsky, S. B. "Political Socialization in Elementary Schools." The Elementary School Journal 87, no. 5 (1987). https:// doi.org/10.1086/461512.

Parmenter, L., C. Lam, Y. Tomita, and H. F. Seto. "Locating Self in the World: Elementary School Children in Japan, Macau and Hong Kong." Compare: A Journal of Comparative and International Education 30, no. 2 (2000). https://doi. org/10.1080/03057920050034084.

Pratiwi, N., N. Pritanova, and Prodi. "Pengaruh Literasi Digital Terhadap Psikologis Anak Dan Remaja." Jurnal Ilmiah Program Studi Pendidikan Bahasa Dan Sastra Indonesia 6, no. 1 (2017). https:// doi.org/10.22460/semantik.v6i1.p11-24. 
Purwati, L. I., and S. Amri. Panduan Memahami Kurikulum 2013. Jakarta: Prestasi Pustaka, 2013.

Quraishi, U., and F. Rahman. "Political Education for Democracy in Schools." Gomal University Journal of Research 25, no. 1 (2009)

Saepudin, E., K. Suryadi, and E. Malihah. "Deliberative Democracy in Digital Era." International Journal of Scientific E Engineering Research 9, no. 4 (2018). http://www.ijser.org.

Sanusi, A. R., and C. Darmawan. "IMPLEMENTASI PENDIDIKAN POLITIK DALAM MEMBENTUK KARAKTERKEPEMIMPINANLINTAS BUDAYA PADA GENERASI MUDA DEMI MEWUJUDKAN BUDAYA POLITIK PANCASILA(Studi Deskriptif Terhadap Organisasi Kepemudaan Gerakan Pemuda Ansor Jawa Barat)." JPIS: Jurnal Pendidikan Ilmu Sosial 25, no. 1 (2016).

Sarnoto, A. Z. "Konsepsi Politik Pendidikan Di Indonesia." EDUCHILD 1, no. 11 (2012).

Sidik, G. S., and F. Nugraha. "Proses Berpikir Pada Pemahaman Perkalian Dan Pembagian Pecahan [ The Process of Thinking in Mathematical Understanding of Primary School Students Regarding CountingOperation Materials Multiplication and Division of Fractions ]." PEDAGOGIA: Jurnal Pendidikan 8, no. 1 (2019): 45-52. https:// doi.org/10.21070/pedagogia.v8i1.1953.

SIM, J. B.-Y. "Citizenship Education and Social Studies." International Journal of Citizenship and Teacher Education 1, no. 1 (2005).

Sinatra, G. M., I. L. Beck, and M. G. McKeown. “A Longitudinal Characterization of Young Students' Knowledge of Their Country's Government." American Educational Research Journal 29, no. 3 (1992). https:// doi.org/10.3102/00028312029003633.

Sopandi, W., Y. A. Pratama, and H. Handayani. "Sosialisasi Dan Workshop Implementasi Model Pembelajaran Dasar Dan Menengah [ Dissemination and Implementation Workshop of RADEC Learning Models for Primary and Secondary Education Teachers ]." PEDAGOGIA: Jurnal Pendidikan 8, no. 1 (2019). https://doi.org/10.21070/ pedagogia.v8i1.1853.

Sugiyono. Metode Penelitian Kuantitatif, Kualitatif Dan RED. Bandung: Alfabeta, 2009.

- - - Metode Penelitian Kuantitatif Kualitatif Dan RED. Bandung: Alfabeta, 2012.

Sukanti, P. Lestari. "Membangun Karakter Siswa Melalui Kegiatan Intrakurikuler Ekstrakurikuler, Dan Hidden Curriculum (Di SD Budi Mulia Dua Pandeansari Yogyakarta)." Jurnal Penelitian 10, no. 1 (2016).

Sukmadinata, N. S. Metode Penelitian Pendidikan. Bandung: PT Remaja Rosdakarya, 2011.

Suroto. Apresiasi Sastra Indonesia. Jakarta: Erlangga, 1989.

Winataputra, U. S., and Sapriya. "Paradigma Baru PKn Di SD/MI." Modul 1 Paradigma Baru PKn Di SD/MI, 2014.

Windschitl, M. "Framing Constructivism in Practice as the Negotiation of Dilemmas: An Analysis of the Conceptual, Pedagogical, Cultural, and Political Challenges Facing Teachers." Review of Educational Research 72, no. 2 (2002). https://doi. org/10.3102/00346543072002131.

Yanti, N., R. Adawiah, and H. Matnuh. “PELAKSANAAN KEGIATAN EKSTRAKURIKULER DALAM RANGKA PENGEMBANGAN NILAI-NILAI KARAKTER SISWA UNTUK MENJADI WARGA." Jurnal Pendidikan Kewarganegaraan, no. 6 (2016). 
92 | Elementirly Vol. 6 No. 1, January-June 2020

Ziblatt, D. "High School Extracurricular Activities and Political Socialization." The ANNALS of the American Academy of Political and Social Science 361, no. 1 (1965). https://doi. org/10.1177/000271626536100103. 